\title{
The Absence of Individual Freedom in the Arab States affecting Human Development
}

\author{
Waleed Abdel Hadi Oweimer ${ }^{1}$ \\ ${ }^{1}$ Department of Political Science, Mu'tah University, Kerak, Jordan \\ Correspondence: Waleed Abdel Hadi Oweimer, Department of Political Science, Mu'tah University, Kerak, \\ Jordan. E-mail: walidwo@hotmail.com
}

Received: May 27, 2018

doi:10.5539/jpl.v11n3p123
Accepted: July 29, $2018 \quad$ Online Published: August 30, 2018

URL: https://doi.org/10.5539/jpl.v11n3p123

\begin{abstract}
The study aimed at pinpointing the effects of the absence of individual freedom in the Arab States on human development, especially in the countries where people could work ondethroning the ruling regimes, in the absence of projects and plans of development. Also, the study discussed the Turkish modelof releasing individual freedoms and their positive effect on the different aspects of human development. The study's hypothesis is:whererules and laws protect individual freedom, there would be a positive impact on the human development in the community. The study recommendsenhancing the level of human development and individual freedoms in the Arab states, to benefit all people of those states.
\end{abstract}

Keywords: individual freedom, human development, Arab Spring, Turkish Trial

\section{Introduction}

Worldly concern with the idea of human development since the beginning of the 1960 s where numerous studies and researchprojects studyhow to treat problems of communities and peoples and work to them appeared to disclose the ways and correct methods that appeared to disclose the ways and correct methods that lead to people progress, development and analysis ${ }^{1(1)}$, and in the same time theories appeared in the domain. The people in charge seek to be aware of the phenomenon of retardation, and unemployment and methods of solving these problems. The United States of America had called this Eva, the Eva of development. And states went to lay plans, and programs guaranteeing the economic and social development ${ }^{(2)}$.

The concept of human development had appeared apparently since the beginning of the 1990s, that met marketability and fame in various states of the world. Many states and the international regional organizations, headed by the United Nations Organization, entrusted specialconcernabout human development, especially in the third world. So many of them developed their programs and their associations to serve this goal, in the track of developing the people of those states, that marks of delay and retardation started to be reflected on a large section of their peoples, and the technical and economic gap started to increase between the states of the North and states of the South at a great form, that was negatively reflected on citizens of the states of the Third World and the living levels retreated and rates of poverty and unemployment at a great deal, and discussion of study about causes of development trends tumbling in most of the third world states at a general form.

There upon and in spite of the positive register of the accomplishments of development plans in some Arab States, but the future ambitions and wish to possess additional elements of economic power and joining the procession of cognitive economy and confronting challenges of hasting local and worldly variables demand the Arab States put in consideration the study of the Arab citizen demands systematically and planned, the first of these demands is the subject of individual freedom that empowers the Arab citizen of innovation and advancement without control on his thought and work, and what guarantees obtainment of advanced levels of the human development and bridging the gap between planning and carrying out.

From this point we explore the effect of individual freedom's absence in some Arab states, whose people could work in dethroning their ruling regimes, such as (Tunisia, Egypt, Lybia, and Yemen) on reality of human

\footnotetext{
${ }^{(1)}$ Anand, Sudhir, and Martin Ravallion, Human development in poor countries : on the role of private incomes and public services, The Journal of Economic Perspectives 7.1 (1993):133-150.

${ }^{(2)}$ Dr. Huda Metikis, The New in the Political Development: a Critical vision, journal of Social Sciences, vol.28, No.2, summer 2000 , P.8.
} 
development in them, and the negative effect of that on projects and plans of development. Also, we will show the Turkish trial in the domain of releasing the individual freedoms since the year 2002 until now, and that will form a live model of releasing the individual freedoms significance in the Arab States. How did that positively affect all sides of the human development in the Turkish state?

\subsection{Objectives of Study}

The study seeks to achieve the following objectives:

1) Discovering the reality of individual freedoms in the Arab states, especially after revolutions of the Arab Spring.

2) Clearing the reality of human development in the Arab states after revolutions of the Arab Spring.

3) Show of the relationship between releasing individual freedoms and the human development.

4) Recognizing the possibility of the Arab states benefitting from other states trials in this domain.

5) Showing the Turkish trial in this domain, which released the individual freedoms for its citizens after ten years of restriction in respect of troops government, and its effect on the human development in it.

\subsection{Significance of Study}

The significance of the study comes from two sides: the first is scientific through submitting scientific information its reference is opinions and points of view of a number of the most important Arab and Moslem thinkers at the beginning of the twentieth century about the effect of the individual freedom absence, on human development, in addition to the trial of the Turkish state in the domain of the human development, and considering it an Islamic state its circumstances are greatly similar to circumstances of many of the Arab States. The study also seeks a scientific addition to the Arab library. The second is a scientific significance through informing the people in charge and decision-makers in the Arab states, that suffer from evident delay in the human development, as a result of suppression and repression of individual freedoms, compared with the Turkish trial in this domain, perhaps to get benefit from that trial in developing their communities and benefit from it in laying policies serve the objectives of development.

\subsection{The Problem of Study and Its Inquiries (Questions)}

Studies that discussed the reality of human development in the Arab states multiplied, and most of them had indicated that the main cause of this delay and retreat refers greatly to bad economic planning, and ignored the negative effect of individual freedom absence on the human development in the Arab states. From this point this study attempts to be aware of the relationship between release of individual freedoms and the human development, through showing the Turkish trial since the year 2002 until now, there upon it had been possible to formulate the main inquiry as follows:

What is the effect of individual freedoms absence on the human development in the Arab states? Branches from this question the following subsidiary questions:

1) What is the reality of individual freedoms in the Arab States, especially after the revolutions of the Arab Spring?

2) What is the reality of human development in the Arab States after the revolutions of the Arab Spring?

3) What is the relationship between the release of the individual freedoms and human development?

4) What is the possibility of the Arab States benefitting from the other states trials, especially Turkey in the domain?

\subsection{Hypothesis of the Study}

Due to the problem of study and its inquiries, a main hypothesis can be formulated as "release of general freedoms of individuals and groups in the Arab states in accordance with law and general system at those states, and maintaining those freedoms by systems, laws, and legislation, that positively no doubt, will be reflected on improving the reality of human development in the Arab states.

\subsection{Limits of Study}

The study includes three determinants. The first is subjective through studying the effect of absence of individual freedom in the Arab states on the human development. The second refers togeographic limits, where the study covers the Arab states that were affected by the Arab Spring, in addition to Turkey, being the successful trial in the domain of human development. The third: time limits from 2010 to 2016. The basic reason in choosing the year 2010 as a beginning of the study, because the revolutions of the Arab Spring started acting in this year, 
through changing some Arab tyrant regimes. The study terminated in the year 2016, when the researcher reached the highest limit of information and data.

\subsection{Concepts of Study}

\subsubsection{Individual Freedoms}

The concept of individual freedom is distinguished for the difficulty of confining it in a specified concept that refers to the difference of looking at it by the difference of the angle through which this concept is looked at, where we find that the definition of the individual freedom philosophically differs from it legally. Also, the concept of individual freedom in the Islamic philosophy differs from western philosophy. The concept of individual freedom differs within supporter of the one intellectual school, and from our reading the variety of those concepts: we find that they share in one fact; it is the ability of action and choice. Individual freedom hassubstantial and morale sides. The most important substantial sides are represented in the personal freedom, transference freedom, residence freedom, possession freedom, and labor freedom. However, the morale sides represented in freedom of believing, freedom of view, and the freedom of learning.

\subsubsection{The Procedural Concept of the Individual Freedom}

It is the freedom of the individual in practising his or her right in participating in decision-making, drawing general policies across fair elections founding the state of institutions and law.

\subsubsection{Human Development}

The concept of human development came as an outcome of economic ideas development, to uncover that humans are development-makers, and they are its goal. This concept had been defined for the first time in deciding the human development, issued from the developmental programmeof the United Nations in the year 1990, that defined it: operations that enlarge people's choices. These choices are not specified, and change across the time. Perhaps the most important of these choices is that people live long, without diseases and discover knowledge, and obtain thenecessary provisions for honored life, in addition to practising the political, economic and social freedoms and making opportunities of innovation and respect of human rights available ${ }^{(3)}$.

\subsubsection{The Procedural Concept of Human Development}

It is the necessity benefit from wealth, energies, and national abilities, growing and developing them with what serves the present and coming generations.

\subsubsection{The Arab Spring}

This term meant the popular revolution represented in peaceful protest movements, started in many of the Arab States in the endings of the year 2010 and the beginning of 2011, affected the Tunisian revolution, that broke out because of Boo Izzizi's burning himself, and worked in dethroning the Tunisian President (reference). The success of the revolution in Tunisia encouraged youths in Egypt to revolt, and led to the withdrawal of the Egyptian President from the government, and hastily followed that the occurrence of revolution in Lybia ended by killing Al-Gaddafi, and the Yemeni president was forced to withdraw after the revolt against him, but in Syria its revolution is still prevailing. Theca uses of these revolts were corruption, economic recession, bad living circumstances, and unfairness of elections ${ }^{(4)}$, and it is obliged to be mentioned that the Independent Newspaper is the first touse this term.

The procedural concept of the Arab Spring: it is a state of protests, demonstrations, disorder and in stability as a result of the Arab Revolutions that occurred between the year 2011 and 2014 and some of them led to breaking out religious, civil and sectarian wars.

\section{The Methodology of Study}

The achieve its objectives, this studydepended on the descriptive and analytical method, that it is one of the analytical techniques leaning on accurate information about a certain phenomenon through a specified period of time, that is for the sake of obtaining scientific results, explained at a subjective way in harmony with the actual data of the phenomenon, and depends on analyzing the political phenomenon. It is in this study the absence of individual freedom that represents the independent variable and its effect on the human development that represents the subordinate variable, and studying each element affected that phenomenon, in addition to studying the subject of analysis to deduce new facts, or drawing the milestones of the future.

\footnotetext{
${ }^{(3)}$ Human development report, UN developmental program, New York 1990, p. 20.

${ }^{(4)}$ Paul Salem, Future of the Arab Future, No. 398, p. 35.
} 


\subsection{Previous Studies}

Report of human development 2013, rise of the south: A human progress in a changing world, United Nations Developmental Programmed, UN, 2014. This report gives an accurate description of the reality of human development in numerous Arab States in addition to the states of the world. And it is possible through this report recognize the reality of the human development in the Arab States and compare it with other states.

Study: "the development and human rights reading inannouncement of the right in development".Dr. Ali Omleil, 1993. The researcher, through his scientific paper submitted to the intellectual symposium concluded by the "Forum of Arab Thought" and the Developing Programmed of the United Nations, the historical development of human rights in the international organizations, and cleared that human rights due to the international charters are classified in to five basic parts, they are: individual safety, law sovereignty, expression freedom, political participation and opportunities equivalence. The researcher in his study assured the existence of strong connection between rights and political freedoms and human development.

Astudy "in the Issue of Freedom", a group of researchers, 1980. The study is a group of essays by Arab prominent thinkers like Mohammad Abdo, Mohammad Rasheed Rida and Amin Al-Rihani. Their essays concentrated on studying the true reasons that shared in the civilized promotion in the first state of Islam and the state of prudent caliphs, and in Europe. And the thinkers wholly agreed that freedom of opinion and confirming the group of basic rights of the citizens were the strong motivation of this promotion.

Study: "the democracy, freedom, and human rights a study in the political sociology", Dr. Hussein Abdel-Hameed Rashwan, 2006. The study discussed in the role of ideas for each of John Luke and Hiegel in developing the individual freedom in Europe. The researcher deduced that both thinkers' ideas played a prominent role in giving birth to the first seeds of rights and individual freedoms in Europe.

Study, "financing the human development in the Arab homeland", Basel Al-Bustani, 1996. The study discussed the human and economic objectives for the human development. The study deduced that the developmental projects in the Arab Homeland had never achieved their human and economic objectives in spite of the abundance of developing programmers that had been applied.

\subsection{Division of Study}

The study had been divided into three topics: the first discussed the individual freedoms in the Arab States after incidences of the Arab Spring. However, the second had discussed the reality of human development in the presents time. Meanwhile the third discussed the Turkish trial in the domain of the individual freedoms and their impact on the human development 2002/2014. Finally, we will summarizethe three topics with a group of results and recommendations.

\subsection{The First Topic: Individual Freedoms in the Arab States after Incidences of the Arab Spring}

The revolutions of the Arab Spring started in 2010 and were represented in their beginnings, with peaceful protest movements covered a number of the Arab States ${ }^{(5)}$, no sooner than they turned into bloody collisions between a number of Arab peoples and their ruling regimes, and some of them could dethrone the symbols of the government, as happened in Tunisia by a decision from the previous president, ZeinelA'bideen Bin Ali to refuge to Saudi Arabia, and the Killing of the Lybian leader, colonel Mua'mer Al-Gaddafi by hands of the Lybian Rebels, with draw al of Previous Egyptian President, Mohammad Husni Mubarak from authority, and in Yemen the President Ali Abdullah Saleh gave up presidency to his Vice-President in accordance with the Gulf Initiative ${ }^{(6)}$. Other Arab peoples are still struggle against their ruling regimes as it is the case in Syria, which the revolution terminated its fifth year, and in return other Arab peoples could do reforms meet their demands as was done in Jordan, Al-Maghreb \& Algeria.

The reasons that led to occurring those revolutions had numerated between internal reasons and others external. The internal reasons had included a great group of the political, economic and social factors ${ }^{(7)}$. Most inhabitants of the Arab States live within social system its basic is tribal and fanaticism, that exhausted plenty of Arab people's capacities. Many of Arab States suffered from evident economic delay, where most of their economy depends on provisions of oil, tourism, or sector of services, in addition to external aids, perhaps the developmental economic schemes be absented from many Arab states, the thing that led to evident retreat in

\footnotetext{
${ }^{(5)}$ Allagui, llhem, and Johanne Kuebler."The ArabSpring \& the role of icts/ introduction". International Journal of Communication 5(2011): 8.

${ }^{(6)}$ Ajami, Fouad. The Arab Spring at one: a year of living dangerously. "Foreign Affairs" (2012): 56-65.

${ }^{(7)}$ GauseIII, F. Gregory. "Why Middle East Studies missed the Arab Spring: the myth of authoritarian stability. "foreignAff. 90 (2011): 81.
} 
living levels for many of their peoples, and in the political side, it is noticed that most of the Arab political regimes are tyrant ones, in which the individual freedoms, which their absence leads to hinder the track of development ${ }^{(8)}$ vanish.Also the economic freedom works to push the economic development ${ }^{(9)}$, and this freedom is connected with the political freedoms ${ }^{(10)}$. And these reasons altogether, in addition to external factors, had formed reasons obliging the Arab peoples' revolutions against their ruling regimes ${ }^{(11)}$.

After the success of anumber of Arab peoples in dethroning system of the government in them an axial question is thrown in front of us, it is did those peoples achieve what they aspire for of freedom, justice and equality? Did their political and developmental reality improve after the dethronement of their ruling regimes? Or they are still falling down under fires of security, grip, and suppressing the individual freedoms and political rights?

Numerous data that can be noticed in a number of Arab states, in which the systems of the government fell down, indicate that the fall of those regimes did not attain them the hoped democracy, states like Lybia, Yemen and Syria (which is still falling down under the regime of Bashhar Al-Assad) had entered civil wars and most of their national ${ }^{(12)}$. So, instead of breezes of freedom, democracy, welfare and stability, which the Arab peoples were waiting, they were afflicted with the spread of the armed terrorist groups at a cancer form, exploiting the security and political vacancy rising in those states. And in the corresponding direction the political regime in other Arab states by new military dictatorships, practiced and still practicing different forms of injustice and tyranny and suppressing individual freedoms, in plea of returning order, security and stability, which had been stolen from them after the fall of their ruling regimes, so they lived a period of political and security vacancy, did occur more of disorder and wreckage of Arab peoples. The best solution from the point of view of the new ruling powers was strengthening the security grip.

The report of the Arab Net for Information of Human Rights issued in the endings of the year 2013 indicates to absence of the transitional justice in the states of the Arab Spring, the matter that led to not accounting the involved people in committing crimes by the symbols of the tyrant regimes, dethroned by revolutions and not presenting them to just prosecutions.

The report discusses the concept of transitional justice, machineries of inquiry and punishment and restructuring in the transitioning justice system, then discusses in detail the case of justice in each of Egypt, Tunisia, Yemen and Lybia, that in spite of passing three years since the breakout of their revolutions, but it did not take any touched steps to perform the system of the transitional justice to treat what it witnessed at previous periods from violations of individual freedoms and human rights.

The report had observed numerous violations of human rights during the revolutions and after them in spite of discourse in the transitional periods about projects of laws to organize the process of the transitional justice, but the symbols of systems of the government subdued to political prosecution some of them is exceptional and the other is natural, in accordance with the different laws in the country without confirming laws of transitional justice till now.

The Arab Net for Information of Human Rights cleared that "The political will in countries of the Arab Spring is prevailed by general trend towards escape of the criminals from punishment, and not following a method of the transitional justice system, and it is in turn, led to tumbling of the reform track, achieving democracy, and not restructuring institutions of the state, accused of corruption, and accounting responsible for committed crimes against peoples, it is what led to repeat those crimes continuously through stages, that followed success of revolutions in dethroning heads regimes of the government"13).

After a (100) days from president Abdel Fattah Al-Seesi's coming into power in Egypt, the Arab Net for Information of Human Rights issued a minimized report about freedom of expression, indicated to existence of evident violations of freedoms of expression, the media and individual freedoms through that period of Abdel Fattah Al-Seesi's government, where performing abundant activities and student demonstrations ${ }^{(14)}$, that uncover corruption and suppression practiced by the new authority in Egypt, in addition to confiscating numerous newspapers and Egyptian magazines following private civil parties in plea that they provoke to overturn the

\footnotetext{
${ }^{(8)}$ BenYishy, Ariel, and Roger R, Betancourt, "civil liberties and economic development", journal of Institutional Economics 6.3 (2010): 281.

${ }^{(9)}$ Weede, Erich, Economic freedom and development: New calculations and interpretations. "Cato J.26.(2006):511.

${ }^{(10)}$ Berggen, Niclas "the benefits of economic freedom: a survey". The Independent review 8.2 (2003): 193-211.

${ }^{(11)}$ Dr. Khalidah, Khalasi, the Arab Spring between revolution disorder, The Arab Future Journal, No. 421, March 2014, p. 230.

${ }^{(12)}$ Abadie, Alberto, Poverty, political freedom, and the roots of terrorism.No. w10859.National Bureau of Economic Research 2004.

${ }^{(13)}$ Escape from punishment, The Arab Net for Information of Human Rights : http://www.anhri.net/cat=5.

${ }^{(14)}$ Meringolo, A. (2015). The struggle over the Egyptian Public Sphere.
} 
regime of the government, in addition to aggression against journalists and arresting them at a tyrant form without aiming accusations to them for long periods ${ }^{(15)}$.Also, the report in spite of political factions rejection, civil community organizations, public council for Human Rights, and large popular sectors of demonstration law, that was issued in the reign of the temporary Egyptian President, A'dli Mansour, and in spite of appeal in its in constitutionality, because of what it included of large restriction of freedoms of expression, but it did seem any response by the president Abdel Fattah Al-Seesi to calls and stands of political factions and organizations of the civil community, in what relates with it, or its amendment, but using this law had been done with exaggerated stubbornness for the sake of muzzling the mouths of critics or opposingthe president. The law had caused increased arrests of opinion- prisoners. In addition to that, the report cleared that issuing public decisions prevent the political work and expressing an opinion at universities ${ }^{(16)}$.

In return, the center (of Right for Democracy and Human Rights) issued its monthly report about conditions of journalism and media freedom in Egypt, where the report observed 25 violation against the Egyptian journalists during September, $2015^{(17)}$.

According to International Amnesty, the year 2014 was disastrous for human rights and individual freedoms, especially in Arab states. The report mentioned that Arab states are still suppresstheiropposes and confiscate their right in opinion freedom and expression. The report indicated to weakness of justice and judicature systems and spread of tyrant arrest and escape of culprits from punishment. The organization provided the increase of torture cases and their spread, especially among the arrested people in the Arab states suffering from tension and conflict $^{(18)}$.

The report also indicated that with the end of 2014 some states like Egypt, Syria, Iraq, lybia, and Yemen, witnessed shocking violations of rights, individual freedom, and armed bloody conflicts, also mentioned that the popular risings that dethroned numerous ruling Arab regimes, became pure faint memory and were evacuated from their true content. So, in Egypt there does not exist what excites plenty of optimism, the military general Abdel Fattah Al-Seesi had come into power (as the report mentioned) after removing the first civil elected president in Egypt after the revolution, and continued a suppressing campaign, did not aim the Movement of Moslem Brotherhood and their allies merely, but political activists from other numerous spectrums, either in the domain of media, or activists for the sake of human rights, so thousands were imprisoned and hundreds were sentenced to death.

In the Gulf States, authorities in Bahrain, Saudi Arabia, and the United Arab Emirates did not save any effort to nuzzle the mouths of political opposing and restricting the individual freedoms. In Syria the forces of the Syrian government waged more of the random military operations on territories to which the civilians refuge in plea of keeping the territories which subdue to it, and restore the territories upon which the armed groups dominate, and the Syrian government did arrest great numbers of its critics and those whom it did suspect that they oppose it, and subdued many of these for torture and conditions of tiresome confiscation, committed actions of illegal killing.

Numerous of the Arab governments had practised the policy of nuzzling the mouths, it restricted the right in freedom of speaking and else of expression forms, including the means of social communication ${ }^{(19)}$. Laws that crime the statements that claimed harming Head of the state, the government, or the judicialresponsibilities of the foreign states. That had been repeated in Bahrain, Jordan, Egypt, Al-Maghreb and O'man ${ }^{(20)}$. In the United Arab Emirates, authorities continued issuing verdicts of long periods of imprisoning against callers for reform, after proceedings in lack of fairness, and determined new legislation to fight terrorism, equalizes between the peaceful protest, and terrorist actions, and exposes its doer to possibility of death, and numerous of Gulf states contrived, including Bahrain, Oman, United Arab Emirates, and Saudi Arabia new authorities to punish the peaceful critics, by depriving them from their nationality and from their rights as citizens. The United Arab Emirates and Kuwait did not delay from practising these competencies through the year 2014.

\footnotetext{
${ }^{(15)}$ Frontie'res, R. S. (2014). Egypt-politically-orchestrated trial ends in long jail terms.

${ }^{(16)}$ Freedom of expression during 100 days from Al-Seesi government: http://anhri.net/?p=133476.

${ }^{(17)}$ Right center for Democracy \& Human Rights, monthly report: http://www.elhak.org/freedome/2015/10/07/134-elhak.html.

${ }^{(18) / e n c y c l o p e d i a / ~ o r g a n i z a t i o n s ~ a n d ~ s t r u c t u r e s / 2015 / 3 / 9 . ~}$

${ }^{(19)}$ Huang, Carol. "Facebook and Twitter Key to Arab Spring Uprising: report". The National.Vol.6.2011.

${ }^{(20)}$ Beinin, Joel, and Fr'ede'ricVairel, eds. Social movements, mobilization,and contestation in the Middle East and North Africa. Stanford University Press,2013.
} 
The freedom of founding associations and joining them did not be safe from the strengthened restrictions, for numerous governments did not allow independent unions, so prevented giving new licenses for jurisprudent organizations and did restrict the action of unions and licensed societies. That was repeated in Algeria, Al-Maghreb and Egypt. In addition to that extremely strengthened restrictions were imposed by a number of Arab governments in the year 2014 (Algeria, Egypt, Bahrain, Yemen, and Kuwait) on the peaceful assemblies, either organized by organizations and associations or individuals or across the social communication.

Also spread in several Arab regimes cases of detention and tyrant arresting, and lengthened confiscation without trial, forcing concealment and the tyrant trials, so thousands were seized in Syria, Egypt, Iraq Kingdom of Saudi Arabia,Bahrain, and Emirates, some of them without accusation, or proceeding. In Egypt one of the judges issued initial verdicts of death against hundreds, accused of participation in bloody attacks on police-stations, after two trials mingled them form of basic deficiency, meanwhile another judge issued verdicts of imprisonment for long periods on three of practitioners in the domain of media without availability of clear evidences. And the Egyptian President issueda decree enhanced authorities of military courts to trial civilians with accusations related with terrorism. And in Bahrain and Emirates thecourts subdued to the commands of the government during trial those accused of accusations related with security, or those accused of harming people in power ${ }^{(21)}$.

Through what preceded we notice evident retreat in individual and group freedoms in numerous Arab states either those in which regimes of the government were dethroned, or those in which regimes of the government are still holding power. For the Arab popular revolutions did not work in achieving the lowest limit of their throng demands, and lasted a memory by which posts sing and mentioned by books of history.

\subsection{The Second Topic: Reality of Human Development in Arab States}

The population of the Arab States amounts to 389,373,000 living in 22 Arab states distributed between both continents of Asia and Africa. The population of Arab states differentiate between states their population exceeds thirty million people, they include six Arab states.They are (Egypt, Sudan, Iraq, Al-Maghreb, and Saudi Arabia), states where their population exceeds ten million people and fewer than thirty million people, they combine four Arab states, they are (Yemen, Syria, Tunisia, and Somalia), but the rest of Arab states the number of their population amounts between some thousands (Jeboti, and Juzzur Al-Gammar) to ten million people. The rate of illiteracy in the Arab states had amounted about \%20 due to 2014 statistics from the whole population. This rate is in case of retreat if compared with previous year, where it amounted about \%35 in the year 2005 fromthe whole population of the Arab states ${ }^{(22)}$.

Indicators of human development due to the concept of UNDP United Nations Development Program includes group of standards ${ }^{(23)}$, the effect of which that organization decides the level of development and growth in the balance of human development for the world states. These indicators combine the following:

1) Health of children and youths.

2) Health of adults and expenditure on health.

3) Education.

4) Control of provisions and specializing them.

5) Social efficiencies.

6) Vanity of personal security.

7) International integration.

8) Environment.

9) Trends of population.

10) Feeling with welfare.

According to the report of the human development of the year 2013 a group of negative notices about reality of human development in numerous Arab states, we notice the following:

The report shows the weakness of performance in the evidence of non-equality between both sexes, as a result increase in mother's death average, and decrease of women share in the parliamentary seats (\%13), it is the

\footnotetext{
${ }^{(21)}$ Report of the International Organization "Amnesty" for 2014/2015, state of Human Rights in the World, 2015, p. 36-42.

${ }^{(22)}$ Mryyan, No. (2014). Demographics, labor force participation, and unemployment in Jordan. The Jordanian labor Market in the New Millennium, 39-63.

${ }^{(23)}$ Mitchell, G. (2006). Problems and fundamentals of sustainable development indicators.
} 
lowest share compared to other districts, and decrease of women participation in man-power (\%22.8), it is also the lowest rate.

The total of the zone share from goods exports value amounts to 546.6 milliard dollars, that is (\%4) only from the total of goods exports in the world, and its value is 13.6 Trillion dollars.

The average of the number of years of study in the zone amount to six years, and it is fewer in a year and a half from the worldly average, by four years of the average in Europe and minor Asia, and the resulting loss from non equality amounts to the highest average in the domain of education (\%39.6) followed by the element of income (\%17.5).

The Arab region occupied the third rank among six regions, from part of gross loss in the evidence of the human development, because of inequality in distributing the developmental acquirements (\%25.4), this average excels with two hundredpercentpoints the average of loss in the worldly guide amounting (\%23.3).

The region registered the lowest rate of employees from the total of population (\%52.6), it is a much fewer rate than the world average amounting to (\%65.8). You notice great difference between countries and regions; for the rate of employees compared to Palestine and high limit in Qatar (\%89.9).

Unemployment average among youths in the region amounts to the highest level in Egypt, where it reaches (\%54.1), followed by Palestine where the average of unemployment of youths amounts to (\%49.6). ${ }^{(24)}$

But what relates with the reality of human development of the Arab states for the year 2014, the report issued in 2006 had cleared that the Arab states occupy a law location in the scales of human development at the level of the world, where the indicator of human development at them amounted to about 0.682, and it is less than the worldly average amounting to 0.694 degrees, and less than average concerning East Asia, the Pacific Ocean, Europe, Latin America, and the Caribbean Sea. If we except the six Gulf states, the other Arab states, especially states of the Arab Spring, in which regimes of the government had been fallen, we find indicators of human development retreated at an attentive form. So, the people of those states had never been able to enjoy qualitative individual freedoms after their popular revolutions, in addition to evident retreat in different phases of human development, either the social or the economic, where we notice that each of Tunisia, Lybia, Egypt, Syria, and Yemen witnessed low level in indicators of human development, worldly confirmed. The rank of those states in the scale of human development at the international level was as follows ${ }^{(25)}$ :

- $\quad$ Lydia's 54 at an average of 0.78 .

- Tunisia is 90 at an average of 0.721 .

- $\quad$ Egypt is 110 at an average of 0.682 .

- Syria is 118 at an average of 0.658 .

- Yemen is 154 at an average of 0.500 .

In addition, the growth of individuals' share from the national income for most of the Arab states had decreased, especially the non-petroleum Arab states. The report of human development for the year 2014 pin-pointed that the big differences in the income may reach to the limit of deteriorating the democratic values in case the rich peoplehad an effect on trends of public opinion (through media).

But with what concern the three dimensions of human development concerning average of age expected at time of giving birth, anaverage of studying years and income. The Arab states had registered evident decrease amounted \%26, compared to Latin America the Caribbean Sea, Europe and Middle Asia.

Eeducation, the average of inequality had reached its highest levels in Arab states \%41, and it is one of the worldly low rates, if compared with the adjacent states of the Third World either in Asia, or Latin America. The report of human development 2013 had deduced existence of negative relationship between inequality and human development, where inequality leads to delay of human development and hindering it.

And in the subject of the women sharing the man in the labor market (due to human development 2014), the Arab women is still delayed from the man at a great form, where the rate of women in age of labor who share in the labor market does not overstep $\% 25$ corresponding $\% 73$ from men ${ }^{(26)}$.

\footnotetext{
${ }^{(24)}$ report of human development for the year 2013: the South Rise. Human advancement in a changing world. UNDP: http://www.un.org/ar/esa/pdf/hrd13/complete.pdf.

${ }^{(25)}$ Report of human development 2014: Going forward in advancement, UNDP http://www.un.org/ar/esa/hdr/pdf/hdr14.pdf.

${ }^{(26)}$ Report of Human Development 2014: go on advancement, UNDP. http://www.un.org/ar/esa/hdr/pdf/hdr14.pdf.
} 
The Arab Spring had shown the deepened cognition by the factors, that can inflame social disorders and violence actions in the community, are not guarantee by the possibility of expecting violence and avoiding it. This type of shocks has destructing results, perhaps cannot be avoided, on progress in human development and onthe power of states.

\subsection{The Third Topic: The Turkish Trial in the Domain of Individual Freedoms and Its Impact on the Human on Development 2014}

The Turkish state since "the Faction of Justice and Development" did hold power in 2002 accomplish numerous democratic reforms, that paced with them steps changed its face, to be move democratic and freedom. Also, the democratic reforms shared greatly in its growth and prosperity in different domains. In this study, we will attempt to witness the Turkish trial in the domain of releasing individual and group freedoms, and impact of that on the reality of its human development.

The present president of the Turkish state, Rajab TayebArdogan believed in Sheikh Adbali's statement, who said: "man has to live. For the state to live", he put this statement into force, and made it amethod of government and administration all along the period of his government, either in the Prime Ministry, or in the Presidency of the state $^{(27)}$.

The Turkish state had paced, since the year 2002 (it is the year of democratic conversion in turkey) large steps in the domain of releasing of individual freedoms, far away from the military institution that secured its grip on the interior for a long period, restricted in it the individual freedoms to the farthest limit, in plea of protecting order and the state. So, the Turkish state retreated extremely, especially in both domains the economic and developmental, and since winning the of Faction of Justice and Development in the Parliamentary Elections, done in November 2002 and forming the first government in the country alone, the faction could achieve more of reforms in all domains, of them 'of course' the political domain. As a result of the political reforms, to which we will lately discuss, the Turkish state could develop and promote in the domain of human development in a form similar to development existing in numerous of European states.

Studier of the Turkish state history before the faction of Justice and Development hold power in 2002, notices the existence of a great distance between the people and the state, the basic demands of the citizens had been ignored long years, either in the domain of democracy, or rights and individual freedoms. And it had been evident after many trials that security policies laid barrier in front of the people had never achieved benefit in obtaining solution of the problems, but to the complete opposite were themselves the cause of aggravating these problems.

And after the year 2002 the Turkish state confirmed a group of constitutional amendments related with the political rights and individual freedoms of the citizens ${ }^{(28)}$, shared after wards, in promoting the scale of human development evidently. The most prominent amendments are the following ${ }^{(29)}$ :

Cancelling the case of emergency on 30/11/2002 after applying it for 15 years. Shortened during this period the rights and individual freedoms in Turkey greatly.

Cancelling courts of security of the state and courts with private authorities in 2004 after 31 years from applying them. Turkey had been classified, because of these courts conflicting to rights of judicature worded in the European agreement of human rights that is by the European Court for human rights.

Releasing the project of national unity and brotherhood in 2002. This project aims at raising standards of democracy in Turkey, by saving liberation and multitude climate allowing different opinions express themselves peacefully, and propositions of solutions are discussed in a sphere of mutual tolerance. And in accordance with this project problems became discussed easily and freely, and there upon the Turkish state became performing the role of social reparation.

Returning the rights of people abstracted from the Turkish nationality in $2009^{(30)}$. Where the military government that ruled Turkey after the coup against the authority in 1980, did abstract the nationality from Turk citizens for political causes and purposely justifications. And due to this law the Turkish nationality had been returned to a

\footnotetext{
${ }^{(27)}$ Prime Ministry (Turkey), Silent Revolution: Harvest of Democratic Change and Conversion in Turkey, Translated by Dr. Tariq Abdel Jalil, Dr. Ahmad Al-A'ydiy, $2^{\text {nd }}$.ed. publications of public \& security consultancy in Turkey 2013, p.7.

${ }^{(28)}$ house, freedom, freedom in the world 2015: the Annual Survey of political Rights and civil liberties. Rowman \& Littlefield, 2015.

${ }^{(29)}$ Özbudun, Ergun. "Democratization reforms in Turkey, 1993-2004". Turkish studies 8.2 (2007): 179-196.

${ }^{(30)}$ Yilmaz, Kürsad, and Murat Tasdan.Organizational citizenship and organizational justice in Turkish primary schools. "Journal of Educational Administration 47.1 (2009): 108-126.
} 
great number of Turkish citizens, whose nationalities were previously abstracted ${ }^{(31)}$, and excused them to return back home and practice their rights and freedoms in the shadow of the state of law ${ }^{(32)}$.

Excuse a civil person to hold the post of secretary general of the national security council after this post was confined to militants. Andin accordance with that preventing militants from holding this post, and the national Security Council converted into a civil institution.

Authorities of military judicature in $2010^{(33)}$ had been decreased. And in accordance with this amendment, the military penal law had decreased affliction on the civilians. Also it has been worded that the militants should be prosecuted before the civilian courts.

Cancelling (Amasya) protocol in the year 2010, by which the militants are allowed to interfere in the activities and social incidents, that occur in cities without obtaining an excuse from the governors.

The military member seat existed inside some institution and public corporations had been cancelled, such as the supreme council for universities, Turkish corporation for the broadcasting service and television, and the highest corporation for news.

Electing the president of the republic became by direct election from the people in $2007^{(34)}$, the aim of that is to weaken the system of guardianship and re inforce the national will. So the Turkish president enjoys a group of competences, and in front of these large competences the Turkish people never had the direct word in electing him, and that had intervened between empowering the people from accounting the president of the republic.By this amendment the people had their word in choosing the president of the republic, who has to deal with the demands of the crowds for the sake of holding his post by support and popular legitimacy.

Issuing a law in the year 2000 allows raising law suits against decisions of the higher military council of consultancy. This step is considered one of important means in protection the basic rights and freedoms for militants. In the past decisions of the military consultancy council were very far from judicial control, for the council did demobilize a great number of militants without allowing them to defend them selves.

Forming committees for facts investigations inside the Turkish parliament in both years 2011 and 2012 their aim is to be aware of the plenty of violation of human rights and freedoms, committed by the military government when waged a coup against the legitimate authority and dethroned the legitimate representatives of the people in 1980.

Absolute intolerance towards afflictions; where this issue is considered one of the important on of the important problems in reports of Turkish Human Rights ${ }^{(35)}$. The Turks had suffered, during the decade of nineties, from affliction in departments of police at an excessive form to a degree that they had never gone to police departments even if he was oppressed or complaining. And was practicing different types of affliction against citizens at police departments. As a result of this new policy it had concerned about training employees in the police institution and giving priority to educate them in the affair of human rights. And due to that a center for research and evaluation of violations of human rights by hands of gendarmerie forces under supervision of the Turkish ministry of interior had been established. In addition to that glorification of penalties on crimes of affliction with the new law of penalties had been done and put into force in 2005. Also a cooperation with the European committee to prevent affliction since the year 2005 till now. All these procedures had shared in improving circumstances and places of confiscation and jails, where they became going with recommendations of the European committee.

Increase of concern by the Turkish judicature with agreements of human rights confirmed by the Turkish state ${ }^{(36)}$. And from the most prominent aspects of this concern is doing amendment of the article 90 from the constitution of 1982. And in accordance with this amendment, it was accepted for the international agreements toa basic reference on the conflicts that may appear, because of laws inclusion of different verdicts on the same subjects. By this amendment the acting ambiguity in the affair of standard values of agreements related with rights and basic freedoms.

\footnotetext{
${ }^{(31)}$ kadirbeyoglu, zeynep. "14 changing conceptions of citizenship in Turkey".(2009): p. 419.

${ }^{(32)}$ Ibid, pp. 36-66, Turkish Prime Ministry. The Silent Revolution.

${ }^{(33)}$ Gürsoy, Yaprak, "The impact of EU-driven reforms on the political autonomy of the Turkish military", South European Society and politics 16.2 (2011): 293-308.

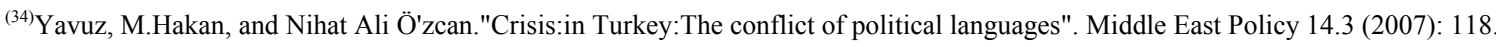

${ }^{(35)}$ pantelić, Nebojša, "European Committee for the prevention of Torture”.Bezbednost, Beograd 47.4 (2005): 565-575.

${ }^{\left({ }^{6}\right)}$ Steiner, Henry J., Philip Alston, and Ryan Goodman. International human rights in context: law, politics morals: text and materials . Oxford University Press, USA, 2008.
} 
Agreement on the right of possessing information. Before the year 2003 the Turkish state was holding a high secret barrier on information related with public institutions, and it was difficult to obtain those information. Andin accordance with the Turkish rules and laws in 2003 the citizens had the right in possessing information, the thing that reinforced the concept of the democratic administration performed on principles of equality, transparency, neutrality and franking. And in accordance with these rules and laws all public administrations became committed to give informationat fundamental form, to the person who submits an application to obtain information for any public administration, and due to that, the principle of protecting information became guaranteed by the constitution in accordance with the constitutional amendment in the year 2010.

Guarantee the freedom of performing any organization that walks together with the European agreement for human rights. In the year 2004 activating the new law for national societies was done, aiming at stabilizing the democratic government and enlarging the domain of the civil community and reinforcing the freedom of performing organizations. Restrictions imposed on performing the national societies had been cancelled, either through this law or through amendments that have been done afterwards. And due to this law and amendments, restrictions related with establisher of the national society were cancelled. Also restrictions related with languages that can be used in their activities were cancelled, and transference from the system of extracting a license to establish a societies into the system of notification, obstacles that were preventing the membership of the employees of the state and students in these societies, also the punishment of prison worded on in the law was replaced by the financial fine.

Reinforcement of assembly and peaceful demonstration right ${ }^{(37)}$ And due to that, periods of meetings and demonstrations postponement had been decreased, and reorganizing the penalties related with disobeyments and facilitate participation of foreigners and their joining meetings and demonstrations in turkey, and it was merely conditioned in using the right of organizing meetings or demonstrations, "the person should be legally competent and overstepped 18 years."

Issuing the law of 2003 calling for facilitating the process of possessing wagfs of groups concerning the minorities and enlarging the domain of freedom ${ }^{(38)}$. For numerous minorities, formerly existing turkey, suffered from religious embarrassment and their right in possession. And due to amendments, which were done on the law of wagfs and private rules, the minorities had been excused to possess Real Estate and deal conclusively with them.also the condition of taking permission from ministers council to register Real Estates in the name of wagfs was cancelled. And due to this amendment the Turkish Prime Ministry issued a communique in 2010 to all institution of the state calling for protecting citizen belonging to the different dogmatic groups, and encourage their respect, assuring that these citizens are impartial of Turkey and they should not be embarrassed at work or violate their rights. In addition to that newspapers concerning minorities had been excused to publish formal announcements. This step had reinforced the economic stand of papers of the minorities.

Invention of the right of raising individual law suit at constitutional court, for in the year 2010 constitutional amendments were done, allowed any person to raise a law suit at the constitutional court, in case of his claim that his basic rights and his freedoms worded in the constitution were violated.

Cancelling the restrictions on the judicial inspection, where a constitutional amendment had been done in 2010 in accordance with them individuals were allowed to refuge to judicature against all decisions of dismissal, except the pensioning off issued by the Supreme Military ConsultancyCouncil, because of promotion procedures or non-existence of occupational degree, and also against decisions of disposition issued from the supreme council of Judges and Attorneys General. In addition to that, the right of employees had been guaranteed in raising a law suit before judicature against both penalties of warning or drawing attention .

Increase of insuring the political factions and their membership in the parliament, were a constitutional amendment in the year 2010 had been done and in accordance with it, cancelling the subject of dethroning membership of the parliamentary representative, who causes in closing his faction, and also a second amendment related with the necessity of achieving the rate of two thirds at voting in the concluded meeting for the sake of issuing a decision by the constitutional court of closing the political factions or depriving them from the aid of the state. The change of voting rate in this subject from three fifths into the two thirds into a more guarantee of the political factions freedom. The significance of this change for thefactions by looking at the penalties which had been applied at an intensified form by the constitutional court in particular.

\footnotetext{
${ }^{(37)}$ Hale,William, "Human rights, the European Union and the Turkish accession process". Turkish Studies 4.1 (2003) pp: 107-126.

${ }^{(38)}$ Grigorialis, loannis N. "On the Europeanization of minority rights protection: Comparing the cases of Greece and Turkey". Mediterranean Politics 13.1 (2008) pp: 23-41.
} 
Doing a constitutional amendment in 2010, done in accordance with it establishing the Public Control Corporation which is considered an important step in the trend of stabilizing the principles of law and rational government sovereignty and protecting individual's rights. And this corporation works under the leadership of the Turkish National Council for the sake of research and discussion of public administration performance and behavior, and the extent of applying the law and justice that is by establishing a machinery od submitting effective and independent complaints, and also to submit the appropriate propositions.

Establishing the Turkish Corporation for Human Rights in the year $2012^{(39)}$ which aims at organizing activities about protecting and developing human rights, where this corporation was entrusted to do the activities concerning protecting and developing human rights and preventing their violation, resisting affliction and mistreatment, discussion in the submitted complaints and applications and following their results, seeking to solve problems and doing studies and researches aiming at following and evaluating emergent development that occur in the domain of human rights, and doing educational activities for this purpose.

Enhancing the child's rights ${ }^{(40)}$, through numerous procedures, where the age of childhood had been raised firstly from 15 to 18 years going together with the United Nations agreement for the child's rights, where the text had been amended to be as follows: "everyone who did not exceed 18 years of age is considered a child". In addition to trial of children was prevented outside courts of the child, together with cancelling the exception related with the domain of occupation of these courts. And due to these amendments done in the law of children courts, establishing children courts at centers, their population exceeds the hundred thousand person was decided. Andin accordance with these amendments, street-children, whose ages below 18 years who are deceived and misguided to participate in incidents of violence, their trial became before courts of the child and not criminal courts.

Enhancing woman rights by doing a group of constitutional amendments ${ }^{(41)}$ in the years (2003/2004/2005/2009/2012). These amendments had covered numerous reforms, increased the political, social, and economic rights of the Turkish woman. From the most prominent of these amendments glorifying the penalties on who commits the crime of killing children for dignity, and cancelling the article that includes lightening penalty on committing of well-known people in crimes of dignity, preventing trading with humans, especiallywomen and children and uprooting organs and punishment, assuring that man and woman enjoy equal rights and the state guarantees achieving this equality before law, organizing a committee to investigate facts, following the Turkish national council, and taking necessary arrangements to prevent aggression on the women and the child, and also the law of opportunity equivalence between man and woman had been issued for the sake of protecting rights of the woman and developing them, and follow up developments locally and internationally as a guarantee of equality between the man and the woman. Also amendment on the law of the Turkish municipalities had been done, in accordance with it, great cities and municipalities whose population does exceed fifty thousand persons were entrusted with the task of opening houses for women and children care.

Increase penalty of using excessive power by policemen against citizens in the incidents where policemen interfere, the penalty of imprisonment strengthened againstpolicemenreached the lowest limit of three months.

In the year 2005 a new list concerning control, confiscation and investigation, in accordance with them, by which of reviewing conditions and executive verdicts for the guarantees worded on, in the context of the basic rights and freedoms were done with what harmonizes the international rights standards for arrested persons, such as improving the conditions of the provisionally detained, and the necessity of informing the relatives and improving the processes of detainment.

Closing prisons, which go with the standards of the United Nations and the Council of Europe, and due to the 208 prisons had been closedand in the same time 81 prisons had been established the go with the standards of the United Nations and the council of Europe.

Doing constitutional amendments in the year 2012, in accordance with them the detainees and prisoners were allowed to attend escorting the funeral of one of the relatives in law or in blood, including relatives of the second degree, and visiting are who is suffering from the dangerous diseases.

\footnotetext{
${ }^{\left({ }^{39}\right.}$ Peterson, Marie Juul Islamic or universal human rights?The OIC's independent permanent human rights commission. No. 2012: 03, DIIS Reports/Danish Institute for International Studies, 2012.

${ }^{(40)}$ AKengin, Hamza "A comparative study on children's perceptions of the child rights in Turkish community of Turkey \&Northern Cyprus". Education 129.2 (20087) p:224.

${ }^{(41)}$ Tocci, Nathalie, "Europeanization in Turkey: trigger or anchor for reform?" South European Society and politics 10.1 (2005) pp.: 73-83.
} 
It was originated in the year 2012 a law, in accordance with it, the freedom of expression and freedom of the press and publication ${ }^{(42)}$, and cancelling penalties cessation of publication in the future had been done, also decisions of confiscation concerning printed papers had been done and law suits and penalties related with committed crimes by press and publication.

Origination of a judge for freedoms for the sake of rein forcing the right of freedom and security of the person, for the judges of the courts previously were issuing decisions to do procedures such as the detainment, detection and caves dropping on calls, and in accordance with new amendments, these issues became from competence of the judge for freedoms the thing that enhanced rights of the accused person and the right of defense.

Enlargement of the range of cultural rights, headed by cancelling obstacles before using and learning languages, different dialects and publication by them and developing than, for making the Turkish Education System a more democratic and multitude system.

The previous group of laws and legislations, related with protecting the political rights and individual freedoms for Turkish citizen, at the different sides of human development in the Turkish state. For in the economic side, the release of rights and freedoms shared in increasing opportunity of labor and investment of the Turkish citizens in different productive sectors, which in turn was reflected on the reality of human development in Turkey.

The Turkish citizen started with work and production supported by the system of laws and legislations, which guaranteed to him the freedom of movement, work, building, and accomplishment. And in accordance with the guide of human development issued by the United Nations in the year 2013, Turkey achieved improvement excelled expectation during the period (1990-2012). Through this period, the Turkish state achieved advancement in the domain of public health, education, transportation communications, and participate the civil community in the government. Turkey became during the period 2011-2012 a commercial partner with more than a hundred international trading companies.

The report of human development clears that Turkey could achieve a great improvement in 2012 from part of income growth and dimensions of human development, unconnected with income, that is health and education. Turkey had occupied the eighth rank worldly among the developing states that could decrease the inability of the human development guide.

Also the report of human development cleared that Turkey in 2012 allowed economic circumstance encouraged building sector, furniture industry, textiles, foods and cars, and all of them are sectors with high ability to absorb manpower's. So, Turkish exports converted into productions that demand a great deal of industrialization and a higher level of technology, and absorbs great numbers of manpower's. That had shared in raising the rate of trade into the gross local production between both years $1990-2010$ from $\% 32$ to $\% 48$.

In addition to that the human development report indicated to that the average of poverty in Turkey amounted to $\% 30$ in 2002 , and that the government expenditure on the social protection did not exceed $\% 12$ of the gross local production, and the social aid expenditure for the poorpeople did not from except for $\% 0.5$ from the gross local production. And after the year 2003 the economic performance improved, the method of social policies changed evidently, where programmers of social aid were enhanced, release of conditioned remittances doing reforms for social security, and change of National Public Health. As a result of these reforms more than one million children met support in the domain of public health, and about 2.2 million people benefitted from aids in the domain of education, and school children received more than 1.3 milliard school texts since the year 2003, and now in Turkeyabout one million children benefit from the free transport to schools.

As a result of these initiatives and else, the percentage rate of population who lives less than 4.30 a day to reach to $\% 3.7$ in 2010 after it had been $\% 30$ in 2002. And in the same period the amounts of money specialized for assisting the poor people and social services increased at an average of three times approximately, to reach its share to $\% 1.2$ from the gross local production, in addition to that the health insurance became available for all people in Turkey. Within the programme of health conversion released in the year 2003 Doctors were specialized for families to reinforce the basic health services, in addition to save the first health care and the free of charge care at emergency conditions. Results were quick and encouraging, it is the first time nearly in which all children obtain free regular vaccination, and seven million pupils get milk freely every day, mothers and children get complements of iron and vitamins without returns. And in accordance with the government statistics, the average of suckling babies' death decreased to ten deaths for each 1.000 live birth in the year 2010, after it

\footnotetext{
${ }^{(42)}$ sezgin, Dilara, and Melissa A. Wall. "Constructing the Kurdsin the Turkish Press: a case study of Hürriyet newspaper". Media, Culture \& Society 27.5 (2005) pp: 787-798.
} 
had been 29 deaths in 2003 . This decrease which amounted to thirty in eight years, greatly surpasses the decrease which had been specified in the frame of developmental objectives of the millennium.

The policies overstep for the interest of children, health care, and education, to provide aid to the local communities. The government had started its new programmers for the social support in the year 2008 aiming enhancing the social coherence, and guaranteeing integration, especially in the eastern territories of less growth in Turkey. The objectives of projects, which amounted some thousands until now and overstep to originate labor opportunities in territories with low income, to cover submitting support to women and youths to express themselves across cultural, technical and athletic accomplishments ${ }^{(43)}$.

\section{Results and Recommendations}

The study's most prominent results are:

Individual freedoms and political rights in many Arab States, especially the Arab States, which their people revolted against tyranny, despotism and domination, practised by regimes of the government. Although some of those people were successful in dethroning regimes of the government at them, they did not enjoy afterwards individual freedoms and political rights as they were ambitious.

Retreat of human development levels in many of Arab States, especially the Arab states, which were successful in dethroning regimes of the government and hoped to develop their developmental reality that caught inability and clear retreat during the reign of some corrupted Arab regimes.

Existence of strong direct relationship between releasing the individual freedoms and promotion in the scale of human development at the level of the world. The study had deduced this result after witnessing the Turkish trial, especially after the year 2002 till now. Before this period Turkey was falling down under the government of militants, who confiscated rights, and individual freedoms of the Turks evidently and that was negatively reflected on the human development. But after the year 2002, the Turkish state issued a group of legislation, laws and system greatly shared in releasing the Turkish citizen and his enjoyment with more of rights and individual freedoms, and that positively had been reflected on the development of different sides of the human development in the Turkish state afterwards.

Increase of worldly concern at the level of the international, Worldly and regional organizations with the subject of human development, rights, and the individual freedoms, represented in issuing a group of laws and legislations which specify rights and individual freedoms and protect them. Either in the United Nations, in the European, or in North America.

Development of rights and individual freedoms did not come all at one time, but developed across numerous time stages, started from the age of renaissance in the Sixteenth Century till nowand still in the way to develop.

The study deduced the correctness of the scientific hypothesis from which it started. Where it found that the more states released rights and individual freedoms and protected them with laws and legislations, the most that reflected positively on the human development in the community.

Through the show of previous results, and completing the subject, we propose some recommendations, that we hope, in case of confirming them, to share in raising the level of human development and freedoms in the state of the third world in general, and the Arab States in particular, the matter that will positively be reflected on the people of those states. The most important of these recommendations are:

Necessity of commitment to the worded standards in the main international treaties related with human rights, especially signed by most of the Arab States.

Necessity of commitment with standards of human rights internationally acknowledged at the formation of laws and legislations in the Arab States.

Supporting efforts of institutions of the civil community in the Arab States, especially the concerned with human development and individual freedoms.

Intensifying dialogues and direct discussions between the ruling regimes and citizens in the Arab States in spheres of freedom and democracy, where parties of the government be aware of their people's ideas and trends and response with them for the interest of both parties.

\footnotetext{
(43) united Nations Developmental Programme (UNDP), United Nations Corporation and the Human Development for the year 2013 New York, 2013 pp. 18-85.
} 


\section{References}

Abadie, A. (2004). Poverty, political freedom, and the roots of terrorism. National Bureau of Economic Research. https://doi.org/10.3386/w10859

Abdo, M. (n.d.). The Message of Monotheism.

Abu Thabi about Environment and Energy, Conference of Environment and Energy, Abu Thabi, 2-5/11/2003.

Ajami, F. (2012). The Arab Spring at one: a year of living dangerously. Foreign Affairs, 56-65.

Akengin, H. (2008). A comparative study on children's perceptions of the child rights in Turkish community of Turkey \& Northern Cyprus. Education, 129(2), 224.

Allagui, L., \& Kuebler, J. (2011). The Arab Spring \& the role of icts/ introduction. International Journal of Communication, 5,8 .

A'marah, M. (1972). The Complete Works of Imam Mohammad Abdo (Part 6). The Arab Association for Studies and Publication, Beirut.

Anand, S., \& Ravallion, M. (1993). Human development in poor countries: On the role of private incomes and public services. The Journal of Economic Perspectives, 7(1), 133-150. https://doi.org/10.1257/jep.7.1.133

Beinin, J., \& Fr'ede'ric, V. (Eds.). (2013). Social movements, mobilization, and contestation in the Middle East and North Africa. Stanford University Press.

BenYishy, A., \& Roger, B. (2010). Civil liberties and economic development. Journal of Institutional Economics, 6(3), 281. https://doi.org/10.1017/S1744137410000081

Berggen, N. (2003). The benefits of economic freedom: A survey. The Independent review, 8(2), 193-211.

Center of Right for Democracy and Human Rights a Monthly Report. Retrieved from http:/www.elhaq.org/freedome/2015/10/07/134-elhaq.html:encyolpedia/organizationsandstructures/2015/3/ 9

Escape From Punishment. (n.d.). The Arab Net for Human Rights Information. Retrieved from http://www.anhri.net/cat=5

Freedom of Expression during the First 100 days from As-Sisi's Government. Retrieved from http://www.anhri.net/?p=133476

Frontie'res, R. S. (2014). Egypt-Politically-orchestrated trial ends in long jail terms.

Gasper, D., \& Irene Van, S. (2003). Development as Freedom V-V and as What Else?. Feminist Economics, 9(2-3), 137-161. https://doi.org/10.1080/1354570032000078663

Gause III, F. G. (2011). Why Middle East Studies missed the Arab Spring: the myth of authoritarian stability. Foreign Affairs, 90, 81.

Ghate, C. (2003). The political of Endogenous Growth Theory. The MIT Press.

Grigorialis, L. N. (2008). On the Europeanization of minority rights protection: Comparing the cases of Greece and Turkey. Mediterranean Politics, 13(1), 23-41. https://doi.org/10.1080/13629390701862574

Gürsoy, Y. (2011). The impact of EU-driven reforms on the political autonomy of the Turkish military. South European Society and politics, 16(2), 293-308. https://doi.org/10.1080/13608746.2011.577950

Hafez, M. (1988). Universal Announcement of Human Rights in the Arab States. Al-Mustagbal Al-Arabi Journal, (117).

Hale, W. (2003). Human rights, the European Union and the Turkish accession process. Turkish Studies, 4(1), 107-126. https://doi.org/10.1080/714005714

House, Freedom. (2015). Freedom in the World 2015: The Annual Survey of Political Rights and Civil Liberties. Rowman \& Littlefield.

Huang, C. (2011). Facebook and Twitter Key to Arab Spring Uprising: Report. The National, 6.

Kadirbeyoglu, Z. (2009). 14 changing conceptions of citizenship in Turkey. P. 419.

Kawakibi, A. R. (1991). Natures of Disposition and Demises of Removal. Mofem for Publication, Algeria.

Kawari, A. K. (1985). Towards a Replacement Strategy of the Comprehensive Development: General Features of the Strategy of Development in the Frame of the Union of Cooperative Council Countries and their 
Integration with the Rest of Arab Countries. Center for Studies of the Arab Unity, Beirut.

Khalasi, K. (2014). The Arab Spring Between Revolution and Disorder. Al-Mustagbal Al-Arabi Journal, (421).

Media Production Center. (2006). The Lasting Development in the Arab States: Between Reality and Hoped. University of King Abdel Aziz, Saudi Arabia.

Meringolo, A. (2015). The struggle over the Egyptian Public Sphere.

Metekis, H. (2000). New in the Political Development: Critical Vision. Journal of Social Science, 28(2).

Mitchell, G. (2006). Problems and fundamentals of sustainable development indicators.

Mryyan, N. (2014). Demographics, labor force participation, and unemployment in Jordan. The Jordanian labor Market in the New Millennium, 39-63. https://doi.org/10.1093/acprof:oso/9780198702054.003.0002

Mughrabi, S. A. G. (1922). The Scientific Freedom in Islam (Part 1). As-Salafeyah Press, Cariro.

Omleil, A. (Ed.). (1994). Human Development in the Arab States. Arab Thought Forum, Amman.

Özbudun, E. (2007). Democratization reforms in Turkey, 1993-2004. Turkish Studies, 8(2), 179-196. https://doi.org/10.1080/14683840701312195

Palestinian Center for Human Rights. (1999). Right in Freedom of Expression and Right in Peaceful Assembly in the Shadow of the Palestinian National Authority-Case of Ghaza Strip, May 1994 - December 1998. Ghaza.

Pantilić, N. (2005). European Committee for the Prevention of Torture. Bezbednost, Beograd 47(4), 565-575.

Peterson, M. J. (2012). Islamic or universal human rights? The OIC's independent permanent human rights commission. DIIS Reports/Danish Institute for International Studies.

Report of International Amnesty Organization for the year 2014/2015, case of Human Rights in the World, 2015.

Sa'doon, J. (1998). Role of the Private Sector in Development, A Paper Submitted to a Symposium of Converting the Public Institutions into the Private Sector and Role of the Stock Market, Casa Blanca (Ad-DarelBayda').

Scully, G. W. (1988). The institutional framework and economic development. The Journal of political Economy, 652-662. https://doi.org/10.1086/261555

Sezgin, D., \& Wall, M. A. (2005). Constructing the Kurds in the Turkish Press: a case study of Hürriyet newspaper. Media, Culture \& Society, 27(5), 787-798. https://doi.org/10.1177/0163443705055735

Steiner, H. J., Alston, P., \& Goodman, R. (2008). International human rights in context: law, politics morals: Text and materials. Oxford University Press, USA.

Tocci, N. (2005). Europeanization in Turkey: trigger or anchor for reform? South European Society and politics, 10(1), 73-83. https://doi.org/10.1080/13608740500037973

Tunisi, K. D. (1972). Straightyer Tracks in Recognizing Conditions of Realms (2nd ed.). Al-Dar Al-Tunisiyah, Tunisia.

Turkish Prime Ministry. (2013). The Silent Revolution: Harvest of Change and Democratic Conversion in Turkey, Translated by Dr. Tareq Abdel Jaleel, Dr. Ahmad Al-A'ydi (2nd ed.). Security and Public System Consultancy Publications in Turkey.

United Nations Developmental Programme, Report of Human Development 2000 Human Rights and Human Development: http://www.pogar.org/publications/other/undp/hr/hr-missinglink-00e.pdf

United Nations Developmental Programme, Report of Human Development of the year 2013: Rise of the South. Human Advancement in a Changing World: http://www.un.org/ar/esa/hdr/pdf/hdr13/complete.pdf

United Nations Developmental Programme, Report of Human Development 2014: Going on in Advancement http://www.un.org/ar/esa/hdr/pdf/hdr14.pdf

Weede, E. (2006). Economic freedom and development: New calculations and interpretations. Cato J., 26, 511.

Yavuz, M. H., \& Özcan, N. A. (2007). Crisis in Turkey: The conflict of political languages. Middle East Policy, 14(3), 118. https://doi.org/10.1111/j.1475-4967.2007.00317.x

Yilmaz, K., \& Tasdan, M. (2009). Organizational citizenship and organizational justice in Turkish primary schools. Journal of Educational Administration, 47(1), 108-126. https://doi.org/10.1108/09578230910928106

Zeyadah, M. (2001). The Civil Community and the State in the Modern Arab Renaissance Thought (2nd ed.). 
Center for Studies of the Arab Unity, Beirut.

Zrookhi, I. (2009). Freedom in the Modern Arab Thought. Al-Mustagbal Al-Arabi Journal, (359).

\section{Copyrights}

Copyright for this article is retained by the author(s), with first publication rights granted to the journal.

This is an open-access article distributed under the terms and conditions of the Creative Commons Attribution license (http://creativecommons.org/licenses/by/4.0/). 